\title{
DRUSKININKŲ MIESTO PLANINĖS ERDVINĖS KOMPOZICIJOS YPATUMAI
}

\author{
Algimantas Mačiulis \\ Architektūros katedra, Vilniaus dailès akademija, Maironio g. 6, LT-01124 Vilnius, Lietuva \\ El.paštas algmaciulis@yahoo.com \\ Iteikta 20081222
}

\begin{abstract}
Santrauka. Druskininkuose susiformavo nevientisa, išskaidyta plano struktūra. Senoje miesto dalyje yra daugiau susiformavusių, užbaigtų miesto erdvių, kitose miesto dalyse vyrauja nevisiškai suformuotos ar tiesiog chaotiškos miesto erdvès, kurias būtina tobulinti arba formuoti iš naujo. Aštuntajame devintajame dešimtmečiuose statyti naujieji miesto urbanistiniai dariniai, ypač aukštybiniai pastatai, pasižymintys agresyvia invazija ị aplinką, iš pagrindų keite miesto siluetą, panoramas, labai pažeide gamtos ir architektūros santykị. Atkūrus Lietuvos nepriklausomybę, šalia gydomosios reabilitacinès funkcijos, išnaudojant dẻkingą gamtinę apylinkių situaciją, kurorte kuriama nauja perspektyva - pramoginių paslaugų, turizmo programa.
\end{abstract}

Reikšminiai žodžiai: miesto plano struktūra, erdvinẻ kompozicija, miesto erdvès, miesto siluetas, statinių mastelis, rekreacinis pažintinis ir pramoginių paslaugų turizmas.

\section{Ivadas}

Miesto turinys - savita miesto forma, jo konkretus vaizdas, apibūdinamas remiantis šiais parametrais: miesto siluetu bei panoramomis, vidaus erdvemis, ypač reikšminga yra miesto gamtinè situacija. Miesto vizualinis identitetas suvokiamas plačiai - pradedant nuo miesto istorinès raidos, ją veikiančių socialinių ir ekonominių sąlygų, toliau - atsižvelgiant ị gamtinę situaciją, miesto teritorijos topologinius, hidrologinius, geologinius, dendrologinius savitumus, vietovès reljefo ypatybes, vertinant miesto antropogenineje, žmogaus veiklos pertvarkytoje aplinkoje esančių miesto elementų morfotipus, erdvių struktūrą, tūrinès kompozicijos vaizdines erdves ir baigiant architektūros menine forma, kultūriniu kontekstu, semantinèmis prasmèmis.

Formuojant miesto meninį vaizdą, ypatingas vaidmuo tenka miesto vyriausiajam architektui, kuris privalo turèti aiškią miesto architektūros vaizdo viziją, statinių mastelio, meninès formos, vientisos urbanistinès kompozicijos idèją, reikiamas valdymo galias šiems tikslams realizuoti. Savo profesinès veiklos pradžioje (1956-1960 m.) teko dirbti Druskininkų vyriausiuoju architektu, rengti kurorto generalinị planą ir centri- nès miesto dalies detalizuotą projektą (1956-1957 m.) (1 pav.), vèliau 1997 m. kartu su kitais - Druskininku miesto bendraji planą. Šiame straipsnyje kurorto kompozicijos tyrimai suskirstyti i miesto planinès struktūros, tūrinès erdvinès kompozicijos, miesto silueto ir statinių mastelio analizę.

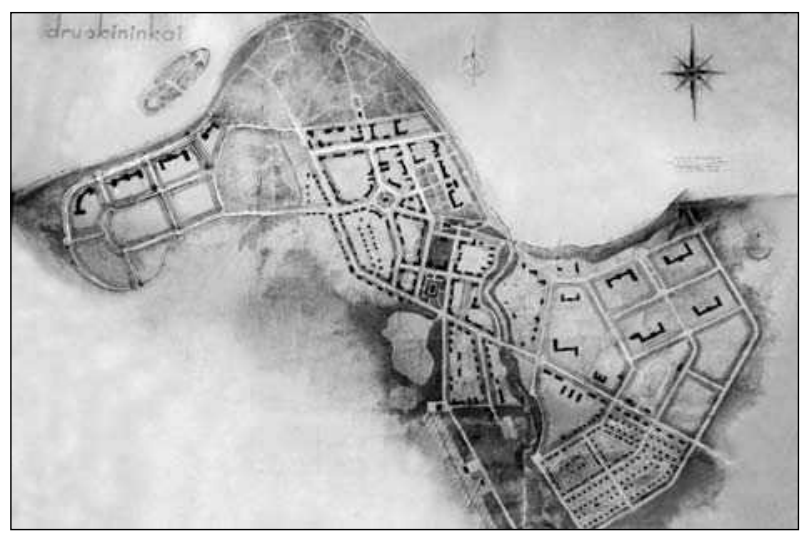

1 pav. Druskininkų centrinès miesto dalies detalizuoto projekto eskizas (autorius A. Mačiulis, 1956-1957 m.)

Fig. 1. Sketch of the detaled project of the central part of Druskininkai (author: A. Mačiulis, 1956-1957) 


\section{Miesto planinė erdvinė struktūra}

Druskininkai - jaunas miestas, iki XVIII a. pab. dar buvęs kaimu, tik $1794 \mathrm{~m}$. juos paskelbus gydomaja vietove ir XIX a. pradžioje ịkūrus gydyklą, kaimo gyvenviete virto miesteliu, o vèliau ir kurortiniu miestu (Miškinis 2002).

Druskininkų planinèje erdvinèje struktūroje galima išskirti šias miesto dalis:

- pirmoji - senamiestis, senoji miesto dalis. Teritorija išsiplètus apie senąsias gydyklas kairiajame Ratnyčios (Ratnyčèlès) upelès krante;

- antroji - naujas miesto rajonas Ratnyčios upelès dešiniajame krante, iš seno vadinamas Paganka (lenk. Poganka), pradèjęs kurtis gana velai, $\mathrm{XX}$ a. pradžioje, plètotas iki Antrojo pasaulinio karo ir sovietmečiu;

- trečioji - Kloniškès, miesto pramonès ir komunalinio ūkio pastatų rajonas, išsidèstęs pačioje atokiausioje pietinèje miesto dalyje, kairiajame Ratnyčios upelès krante, šalia Gardino gatvès;

- ketvirtoji - Kalviškès, „Eglès“ ir „Žilvino“ sanatoriju kompleksas bei gyvenamasis kvartalas;

- penktoji - Ratnyčia, nuo miesto centro ì pietų pusę nutolusi, stichiškai besivystanti gyvenvietè, kurorto priemiestis;

- šeštoji - Baltašiškè, atskira miesto teritorija, besiformuojanti kairiajame Nemuno krante.

\section{Senoji miesto dalis}

Druskininkų senoji miesto dalis susiformavo stačiakampio plano, tačiau neturi aiškios, užbaigtos kompozicijos (2 pav.). XIX a. sekant carinès Rusijos miestų planavimo principais, šioje miesto dalyje bandyta sukurti centrinę miesto aikštę su medine stačiatikių cerkve (pastatyta 1865 m.). Ši rombo formos aikšte (dabar Laisvès aikštè), nors ir jungè pagrindines senamiesčio dalis bei gydyklas, netapo miesto kompozicine dominante, nebuvo planingiau užstatyta. Pagrindine miesto aikšte išliko Bažnyčios aikštè, kurią riboja svarbios miesto gatvès: dabartinè Vilniaus alèja, M. K. Čiurlionio ir V. Kudirkos gatvès. Aikštės viduryje stovinti mūrinè neogotikine Švč. Mergelès Marijos Škaplierinès bažnyčia (pastatyta 1931 m., architektas S. Szylleris) yra vyraujantis aikštès elementas.

1956-1960 m. pradètas formuoti bažnyčios aikštès užstatymas: Taikos ir V. Kudirkos gatvių kampe pastatytas trijų aukštų „Turisto“ viešbutis (architektas A. Sprindys; dabar - viešbutis "Druskininkai“, rekonstruotas 2004 m.; architektai A. Taujanskas, O. Budvytytė; 3 pav.), šalia aikštės iškilo 30 butų gy-

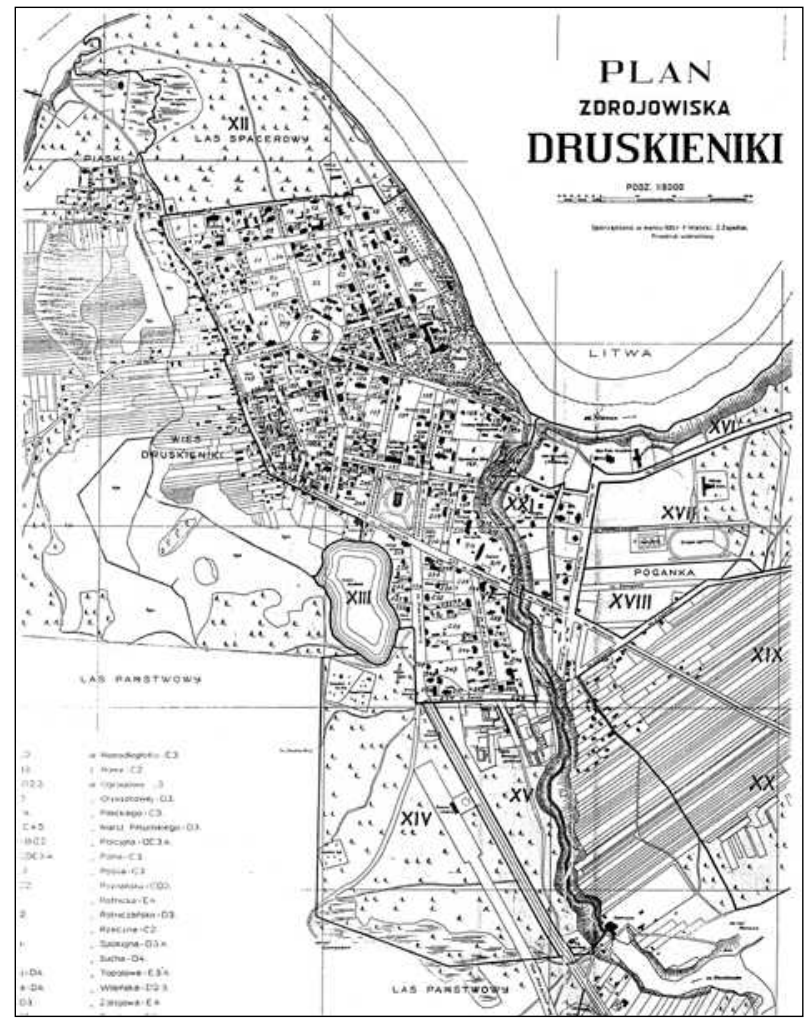

2 pav. Druskininkų miesto planas, $1935 \mathrm{~m}$.

Fig. 2. Plan of Druskininkai, 1935

venamasis namas su vaistine, buitinio aptarnavimo kombinatas, M. K. Čiurlionio ir V. Kudirkos g. sankirtoje - pašto rūmai (architektè V. Furman-Taurienè). $1980 \mathrm{~m}$. nugriovus stilingą moderno stiliaus buvusį pensionatą „Europa“ su restoranu, $1982 \mathrm{~m}$. pastatytas „Pušyno“ (dabar „Sūručio“) sanatorijos antrasis korpusas (architektai A. ir R. Šilinskai), kurio aštuonbriaunè plano konfigūracija ir apvalios architektūrinès formos pažeide Bažnyčios aikštès perimetrinį užstatymo pobūdị (Mačiulis 2007) (4 pav.). Aikštès erdvè pietinèje pusèje organiškai susilieja su atviromis Druskonio ežero ir Vijūnèlès upelès užtvankos erdvėmis, šalia esančiu miško masyvu, tolimomis tamsaus miško kontūro perspektyvomis. Tai labai svarbu kurortui, kai neprarandamas natūralios gamtos ir architektūros tarpusavio ryšys bei harmoninga sąveika.

Miesto planinèje struktūroje Bažnyčios ir Laisvès aikštès neturi tarpusavio kompozicinio ryšio, nesudaro vientisos miesto aikščiu erdvinès sistemos. Vilniaus alejja, anksčiau buvusi viena iš pagrindinių kurorto gatvių, svarbi miesto arterija, dabar skirta vien pèstiesiems (gatvès rekonstrukcija atlikta $1987 \mathrm{~m}$., architektas R. Mickevičius), kompoziciškai nejungia šių aikščių. Pagrindinè miesto transporto magistrale tapo 


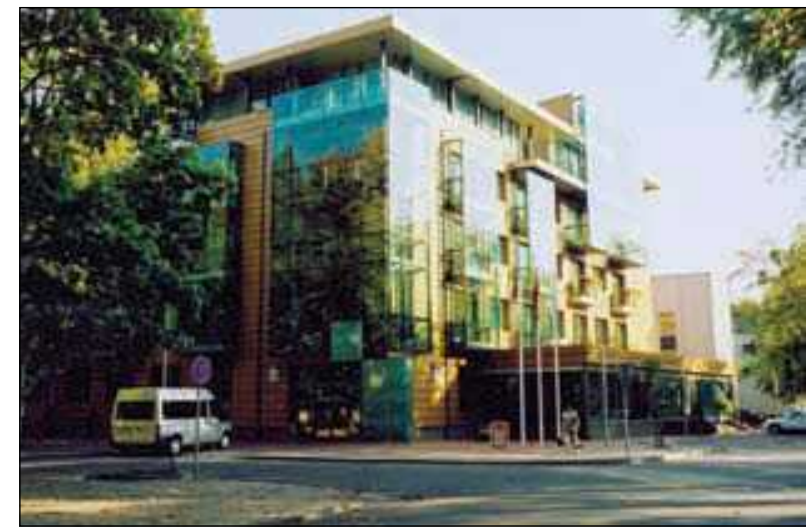

3 pav. Viešbutis "Druskininkai“ V. Kudirkos g. (anksčiau viešbutis „Turistas", autorius A. Sprindys, 1960 m.; renovuotas 2004 m., autoriai: A. Taujanskas, L. Meškys, O. Budvytytè)

Fig. 3. Hotel "Druskininkai" in V. Kudirka st (former hotel "Tourist", author: A. Sprindys, 1960; after renovation in 2004, authors: A. Taujanskas, L. Meškys, D. Budvytytė)

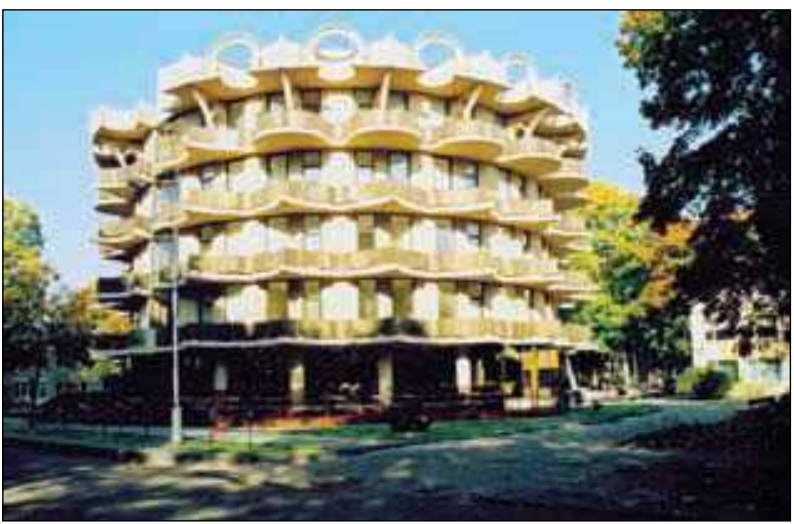

4 pav. "Sūručio" sanatorijos antrasis korpusas, Taikos g. (autoriai A. ir R. Šilinskai, 1982 m.)

Fig. 4. The second block of sanatorium "Sūrutis" (authors: A. Šilinskas, R. Šilinskas, 1982)

M. K. Čiurlionio gatvè, jungianti senamiestị su naująja dalimi - Pagankos rajonu.

Senamiestyje svarbią vietą užima senosios gydyklos su parku (5 pav.) bei balneologijos ir fizioterapijos gydykla (pastatyta 1981 m., architektai A. ir R. Šilinskai; dabar Druskininkų vandens pramogų parkas; gydykla rekonstruota 2006 m., architektai K. Kisielius ir V. Kančiauskas (6 pav.)). Raiškios plastikos ir originalių konstrukcijų kompleksas yra orientuotas ị Vilniaus aleją, kartu formuoja Nemuno krantinès architektūrini vaizdą, tapo vienu iš ryškiausių meninių akcentų senamiestyje, kartu ir kurorto naujo įvaizdžio elementu.

\section{Naujoji miesto dalis}

Naujosios miesto dalies teritoriją rytineje Ratnyčios upelès pusèje sudaro keli komponentai:

1.Abejose M. K. Čiurlionio gatvès pusèse (Pagankoje) susiformavęs stambus prekybos centras (dengta turgavietè, universalinès parduotuvès „Rytas“ bei „Raigardas") ir gyvenamieji kvartalai.

2. Atokiau nuo miesto centro esantis stambus gydomasis kompleksas - 525 vietu „Eglès“ sanatorija su atskira fizioterapijos gydykla, plaukimo baseinu, gydomosios kūno kultūros sale, mineralinio vandens biuvete, taip pat 1000 vietų „Žilvino“ sanatorija, anksčiau skirta žemdirbiams (buvęs Tarpkolūkinis kurortinis ịstaigu susivienijimas).

3.Šalia buvusio Neravų kaimo įsikūręs Kalviškių gyvenamasis rajonas - Neravų (1979 m.) ir Ateities (1986 m.) gyvenamieji kvartalai, kur, be gyvenamųju namų, pastatyta „Liepaitès“ parduotuvè, „Kalviškių“ kavinè-parduotuvé, vidurinè mokykla, vaikų lopšelisdarželis, „Sakalo“ pastatas ir kt.

Tipiniai gyvenamieji namai Pagankoje tarp V. Krèvès, Vytauto, Veisejų ir M. K. Čiurlionio gatvių (gyvenamojo kvartalo autorè - architektè A. Kontarovič), Kalviškių gyvenamieji kvartalai (architektai - A. Kardišius, A. Mickiene ir kt.), taip pat privačių mažaaukščių gyvenamųjų namų kvartalas, išaugęs pirmaisiais pokario dešimtmečiais, - tai sovietinio meto tipinès statybos, nuasmenintos architektūros produktas. Čia sunku rasti kurortui būdingų architektūros bruožų, urbanistinių tradicijų tąsos. Tuo metu buvo ribojamos pastangos ar tiesiog draudžiama kurti savitą, i̦vairesnę architektūrą, atitinkančią kiekvieno miesto skirtingus savitumus bei tradicijas.

„Eglès“ ir „Žilvino“ sanatorijų teritorija, Kalviškių gyvenamieji kvartalai bei Ratnyčios priemiestis yra nutolę nuo miesto centro, tai lyg atskiros, autonomiškos miesto dalys, kompoziciškai nesujungtos ị bendrą miesto urbanistinę struktūrą. Taigi Druskininkuose susiformavo gana nevientisa, išskaidyta plano struktūra. Naujieji miesto urbanistiniai dariniai pasižymi agresyvia stambių architektūrinių tūrių invazija i̇ gamtą.

\section{Miesto erdvès}

Miesto erdvès diferencijuotinos $\mathfrak{i}$ atskirus tipus pagal ịvairius aspektus: 1. Gatvių ir aikščių erdvès, susiformavusios ịvairiu laiku, yra nevienodo amžiaus (laiko aspektas). 2. Uždaros ir atviros, didelès ir mažos, stačiakampès ir netaisyklingos formos erdvès (fizinių savybių aspektas). 3. Erdvès pagal transporto ir pèsčiųjų judrumą jose (dinamiškumo aspektas). 


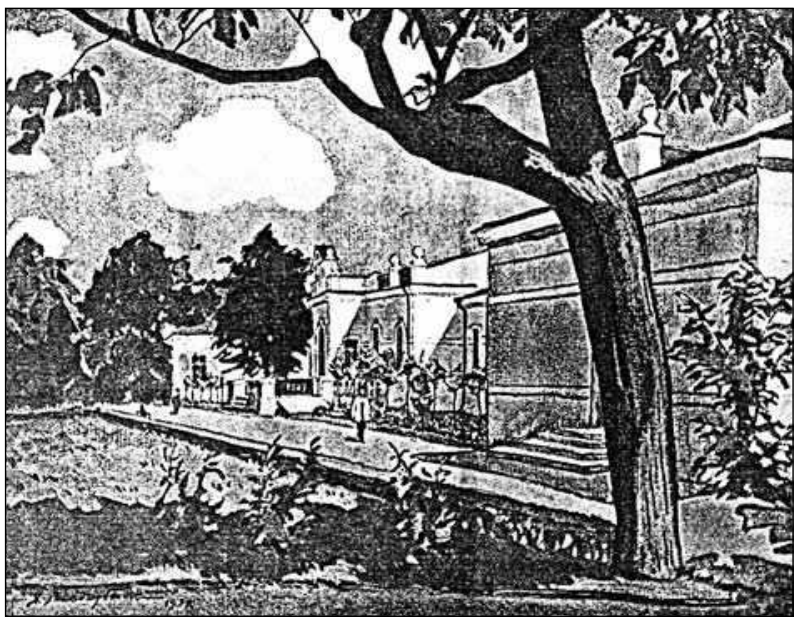

a

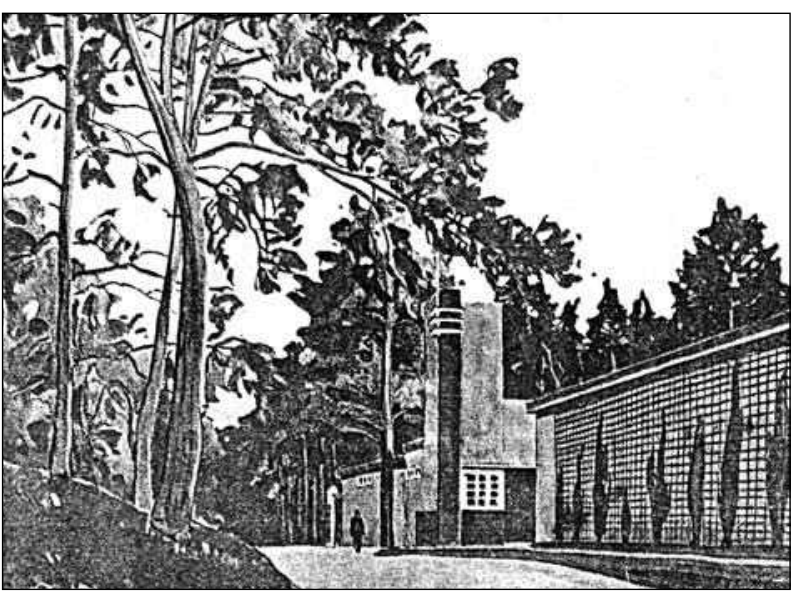

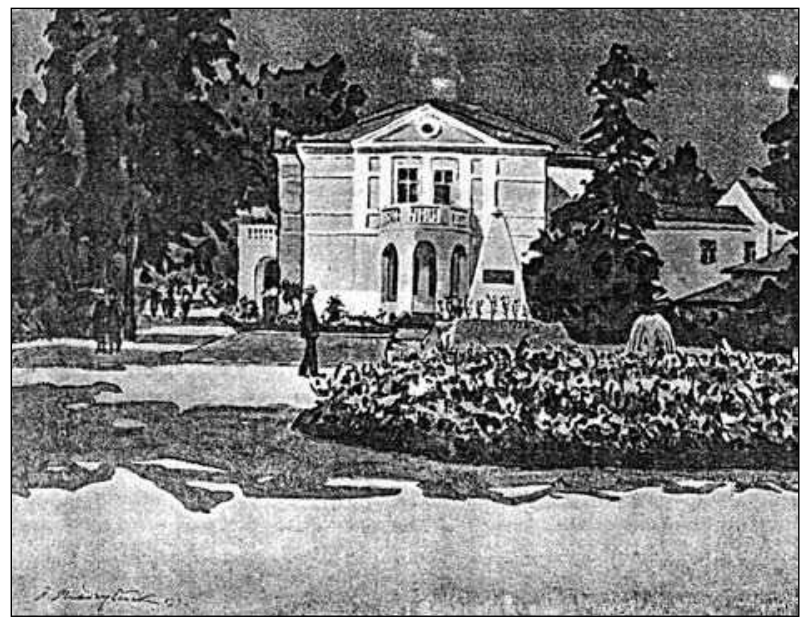

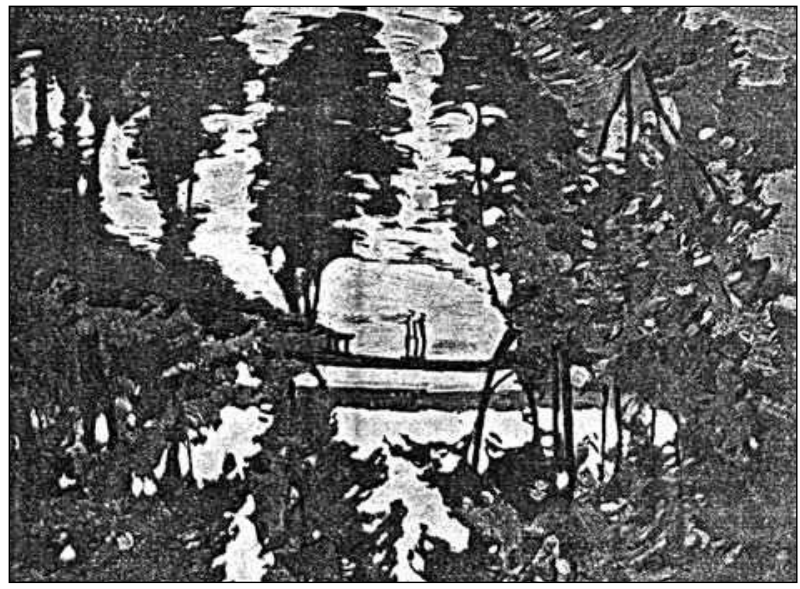

5 pav. Lenkų dailininko Adomo Międzyblockio (1890-1956 m.) piešiniai (1932 m.): a, b - senoji Druskininku gydykla su parku; c - gydomosios fizinès kultūros parkas; $d$ - upelè Ratnyčia įteka į Nemuną

Fig. 5. Drawings of the Polish artist Adam Miedzyblocki (1890-1956): a, b - old sanatorium and park in Druskininkai; $c$ - park of cure physical culture; $d$ - the Ratnyčia river meets the Nemunas

Nagrinejjant Druskininkų miesto erdves, pasirinktas skirstymo pagal kompozicijos užbaigimo laipsnị metodas, artimas V. Jurkšto siūlomiems miestu istorinès aplinkos architektūros kokybès vertinimo kriterijams (Jurkštas 1994: 32-33). Remiantis šia metodika, Druskininkų miesto erdvès išskirtos ị keturis tipus:

A - suformuotos, užbaigtos miesto erdvès, kurių elementų raida nepageidautina arba gali keistis nedaug (Bažnyčios aikštė, Druskonio ežero krantinès, senosios gydyklos ir parkas, M. K. Čiurlionio paminklas, V. Kudirkos ir K. Dineikos gatvess);

B - nevisiškai suformuotos miesto erdvès, jų architektūra dar gali tobulèti, keistis (Laisvès aikštè, Šv. Jokūbo, T. Kosciuškos, Maironio, V. Krèvès gatvès, M. K. Čiurlionio gatvè tarp Šv. Jokūbo ir Veisejjų gatvių,
Nemuno krantinè, Kalviškių gyvenamasis kvartalas, „Eglès“ ir „Žilvino“ sanatorijų kompleksas);

C - indiferentiškos, „bejausmès“ miesto erdvès, kurias būtina tobulinti (gyvenamasis kvartalas tarp M. K. Čiurlionio, V. Krèvès ir Vytauto gatvių, privačių mažaaukščių gyvenamụjų namų kvartalas tarp Vytauto, L. Giros ir Dzūkų gatvių, Antakalnio, Mizgirių gatvės, pramonés rajonas Baravykų gatvèje);

$\mathrm{D}$ - nesuformuotos, chaotiškos miesto erdvès, kurioms būtina architektūros raida (privačių mažaaukščių gyvenamujų namų kvartalai prie Šaltinių ir Lipliūnų gatvių, taip pat prie Sodų, Pakalnès ir Kalnų gatvių, Žalioji, Gluosnių gatvès, Ratnyčios ir Baltašiškès gyvenvietès, Druskininku gatvè, Ratnyčios upelès krantinès, kolektyvinių sodų kvartalas). 


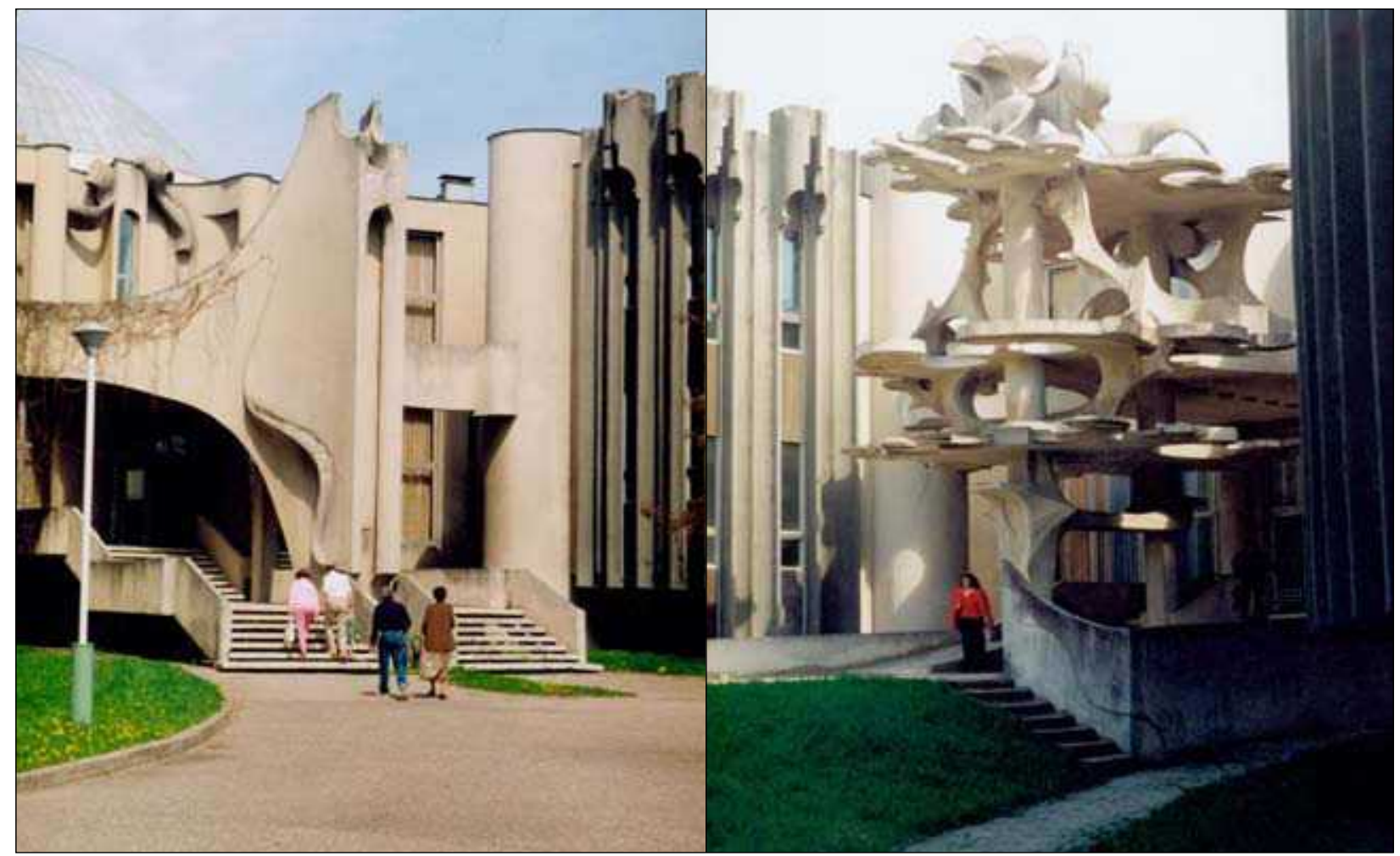

a

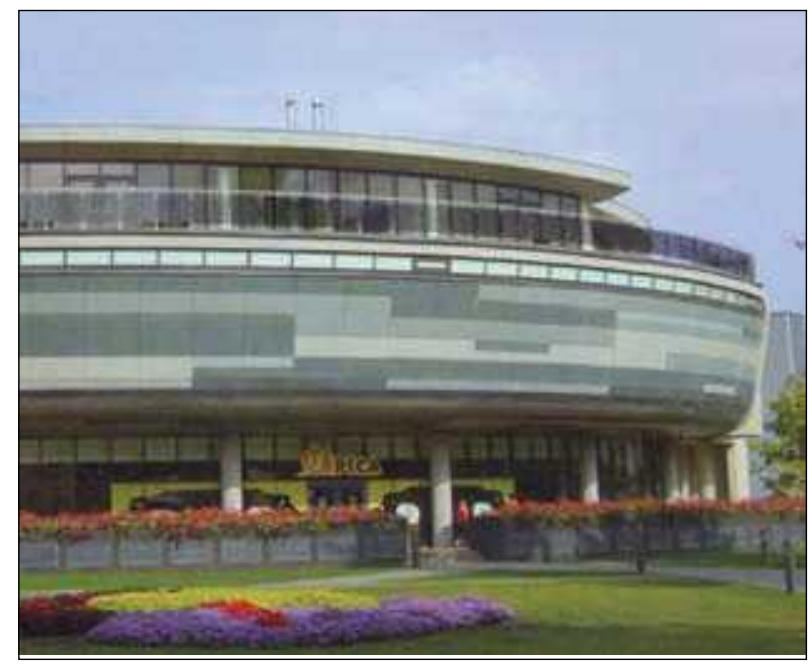

b

6 pav. Fizioterapijos gydykla Vilniaus al. (a), dabar Vandens pramogu parkas (b) (pastatyta $1981 \mathrm{~m}$. pagal A. ir R. Šilinsku projektą, renovuota 2006 m., autoriai: K. Kisielius, V. Kančiauskas)

Fig. 6. Former Sanatorium of Physiotherapy in Vilnius avenue (a), today - Recreational Water Park (b) (first built in 1981, architects: A. Šilinskas, R. Šilinskas; after renovation in 2006, authors: K. Kisielius, V. Kančiauskas)
Miesto plètra yra nesibaigiantis, dinamiškas procesas. Ne visos miesto erdvės gali tilpti ị griežtus erdvių tipų pagal kompozicijos užbaigimo laipsnį klasifikacijos rèmus. Tačiau ši miesto erdvių analizè turètų būti naudinga tolesniam Druskininkų kurorto planavimui, miesto tvarkymui, regeneracijos priemonių vykdymui.

\section{Miesto siluetas. Mastelis}

Druskininkų miesto siluetas formavosi palaipsniui. Iki sovietmečio miesto siluete vyravo žalieji masyvai. Miesto teritorijos apstatymas buvo netankus, o pastatai neviršijo trijų aukštų. Prieškaryje daugiausia kurorto pastatų buvo pastatyta dabartinėse V. Kudirkos, M. K. Čiurlionio, K. Dineikos, Maironio gatvių zonose ir kelios poilsinès - teritorijoje Ratnyčios upelio dešinèje pusèje. Vasarnamiai bei vilos skendo žalumynuose, tik kai kur smaili mediniai jų bokšteliai pakildavo virš medžių, pagyvindavo gatvių išklotines, tačiau miesto panoramoje nedominavo. Miesto siluete tuo metu daugiau išsiskyrẻ raudonų plytų smailas bažnyčios bokštas (7 pav.) bei vila „Linksma“ su mezoninu ir apžvalgos bokšteliu (pastatyta 1905-1909 m.) šiaurinèje Druskonio ežero pakrantèje (8 pav.). Prieš pat karą pastatytas vandentiekio bokštas gydomosios fizinès kultūros parke, Sausojoje gatvèje, vèliau gydy- 


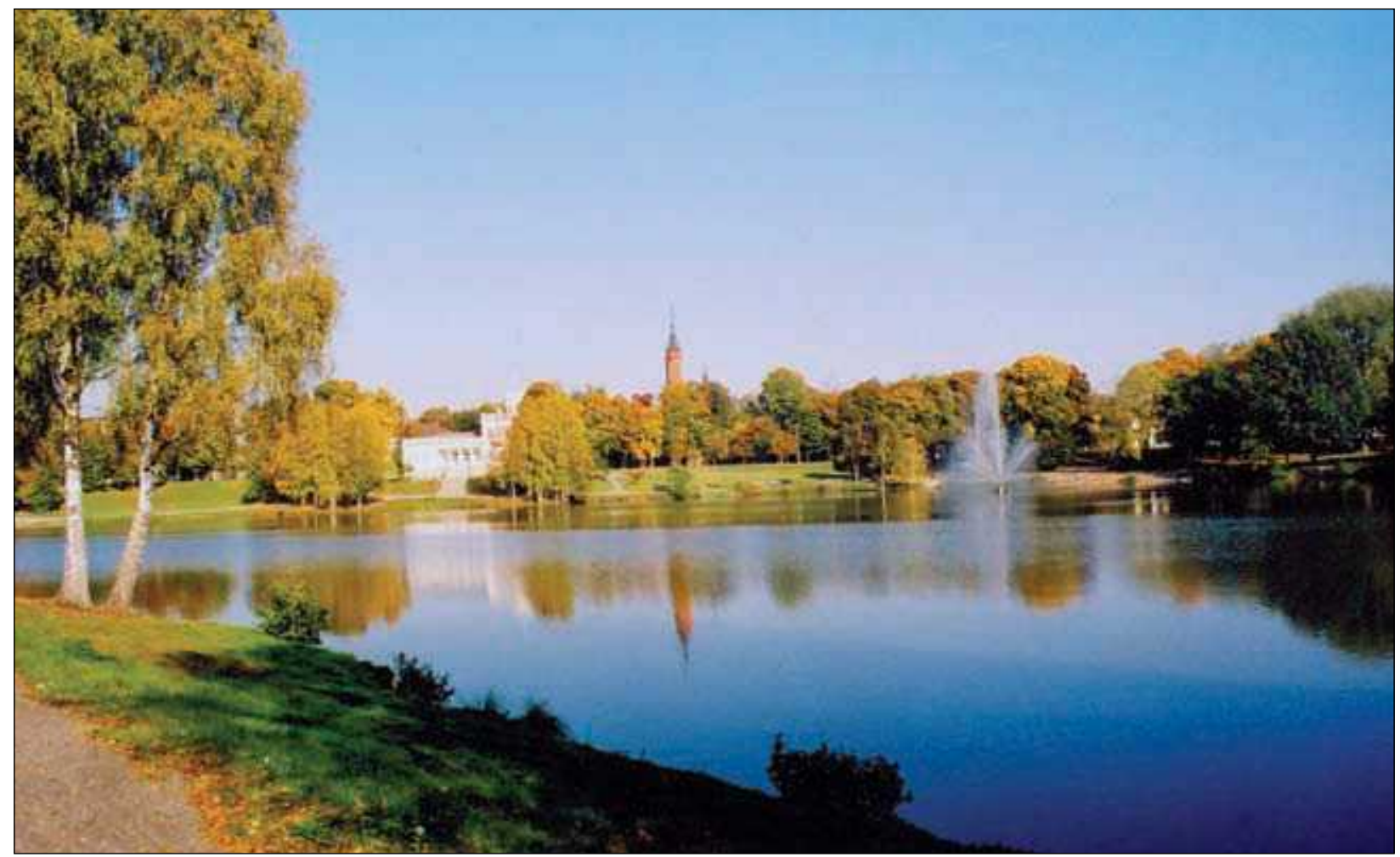

7 pav. Druskininkų miesto panorama nuo Druskonio ežero Fig. 7. Panorama of Druskininkai from the lake of Druskonis

klų katilinès kaminas tapo aukščiausiais vertikaliais akcentais mieste. Žvelgiant nuo Nemuno upès kairiojo kranto pusės, išsiskyre gana stambus horizontalus gydyklų tūris.

Po karo iki 1970 m. miesto siluetas ne daug kuo keitèsi. Be minètų naujų visuomeninių pastatų Bažnyčios aikšteje, 1956-1961 m. kurorte pastatyti ne aukštesni kaip trijų aukštų statiniai: „Druskininkų“ sanatorija V. Krevės gatvèje (architektė G. G. Adomavičienè), naujoji balneologinè purvo gydykla (architektas V. Ulitko), valgykla Šv. Jokūbo gatveje (architektas A. Mačiulis, pastatas neišlikęs), universalinè parduotuve Vilniaus alejoje (architektas V.E. Čekanauskas), rekonstruotas „Pušyno“ poilsio mamų korpusas K. Dineikos gatveje ir kt.

Dirbdamas miesto vyriausiuoju architektu vadovavausi šiais kurorto plètros ir architektūros principais: nepažeisti gamtos ir naujos architektūros santykio, suteikti statyboms tinkamą masteli. I I Druskininkus žmonès važiuoja ilsètis iš didelių miestų, kur vyrauja daugiaaukštè, tanki statyba, poilsiautojai čia tikisi rasti visai kitokią aplinką, įsikurti ne aukštuose pastatuose, o atvirkščiai - mažaaukščiuose, esančiuose parke ar miške, pasijusti arčiau žemès (Mačiulis 2007). Taigi
Druskininkų kurorte kurị laiką buvo išsaugotas prieškariu susiformavęs neaukštų pastatų, skendinčių žalumynuose, mastelis, architektūrinis vaizdas.

1970 m. sudarytame Druskininkų miesto centrinès dalies suplanavimo projekte (parengè MSPI Kauno filialo architektai A. Steponavičius, V. Medelis ir kt.) siūloma didinti statybų aukštingumą, numatomi aukšti, vertikalūs architektūriniai akcentai (Druskininkų miesto centrinès dalies ... 1970). 1979 m. patvirtintas naujas Druskininkų miesto generalinis planas (parengè MSPI Kauno filialo architektai P. Janulis, A. Pucas, dalyvaujant Druskininkų miesto vyriausiajam architektui V. Petkevičiui ir kt.), kur „siekiant miesto silueto paįvairinimo" numatoma statyti stambius, aukštus sanatorijų ir gyvenamųjų namų statinius (Druskininkų miesto generalinis planas ... 1979). Igyvendinant šias nuostatas pastatytas naujasis vienuolikos aukštuc „Nemuno“ sanatorijos korpusas T. Kosčiuškos gatvėje (architektai E. Tamoševičius, P. Adomaitis), agresyviai iškylantis žalioje miesto panoramoje, labai pažeidžiantis gamtos ir architektūros santykị. Vèliau miesto panoramoje iškyla dešimties aukštų „Baltarusijos“ sanatorijos naujieji korpusai Maironio gatveje, aštuonių aukštų 


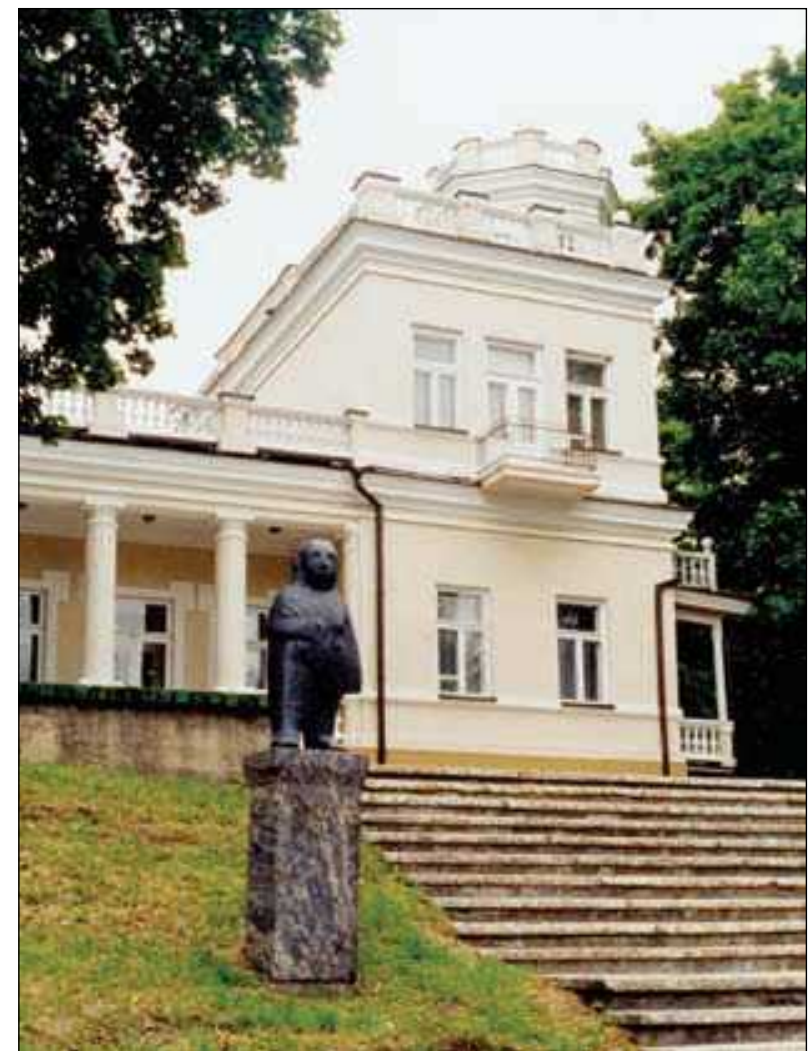

8 pav. Vila "Linksma“ ant Druskonio ežero kranto, priekyje skulptūra "Gimimo diena" (skulptorè K. Jaroševaitè, 1987 m.) Fig. 8. Vila "Linksma" located on the bank of the Druskonis lake with a sculpture "Birthday" in front (sculptor: K. Jaroševaitè, 1987)

„Vilniaus“ sanatorija K. Dineikos gatveje (architektaiA. ir R. Šilinskai), septynių aukštų „Lietuvos“ sanatorija su fizioterapijos gydykla, uždaru plaukimo baseinu ir poliklinika (architektai V. Balčiūnas, A. Aronas, A. Paslaitis, L. Raškauskas). Šalia „Eglès“ sanatorijos išaugo stambus gydomasis kompleksas, 1000 vietų „Žilvino" sanatorija. Be didelių sanatorijų pastatų, kurorte statomi ir devynių dešimties aukštų bokštiniai gyvenamieji namai kvartale šalia M. K. Čiurlionio ir Vytauto gatvių, taip pat Kalviškių gyvenamajame kvartale. Šie vertikalūs architektūriniai miesto akcentai, iškylantys aukštai virš žaliojo medžių masyvo, iš pagrindụ keitè miesto siluetą, ypač miesto senosios dalies tūrinę erdvinę struktūrą.

1987 m. MSPI Kauno filiale parengtame Druskininkų miesto centrinès dalies detalaus suplanavimo projekte (architektai A. Pucas, J. Toliušienè ir kt., dalyvavo E. Palavinskas) pagrindinès kurorto plètros koncepcijos keičiasi: smerkiama ankstesnè nuostata didinti pastatų aukštingumą, statybų chaotiškumas, kritikuojami stambūs aukšti pastatai, „trikdantys landšafto

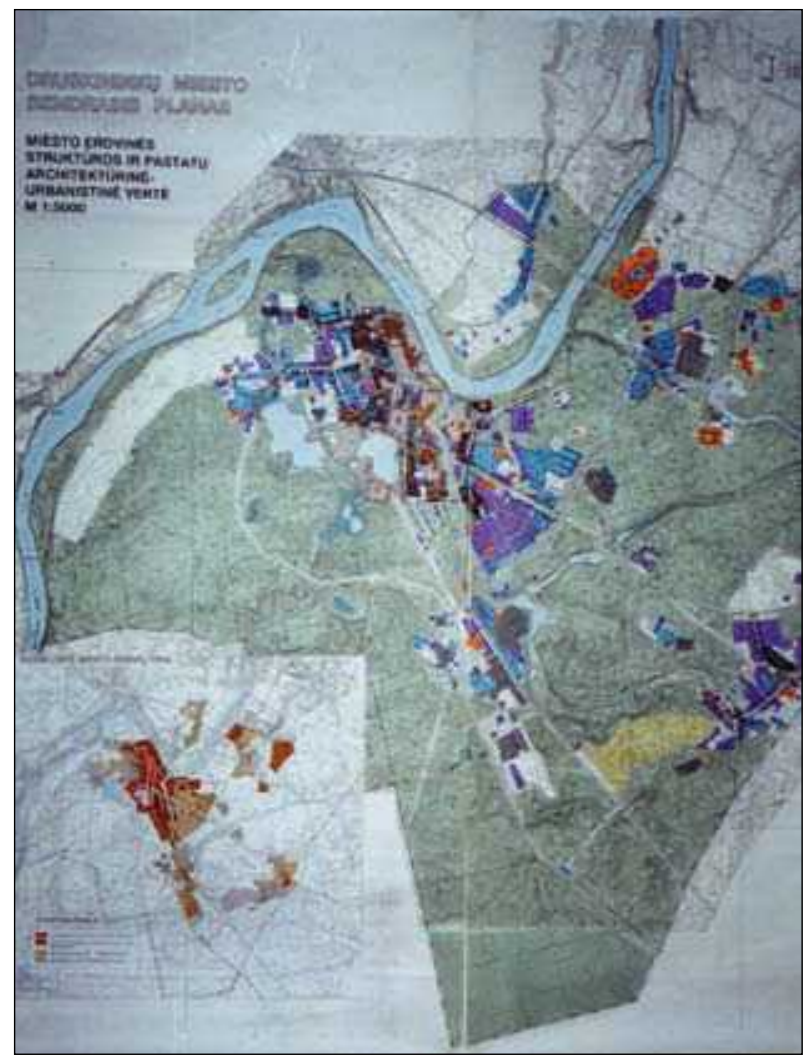

9 pav. Druskininku miesto bendrasis planas (darbo vadovas S. Čereškevičius, architektūrinès dalies vadovè N. Dičiuvienė, J. Bučas, L. Dringelis, A. Mačiulis, V. Stauskas ir kt., 1997 m.). Miesto erdvinès struktūros ir pastatų architektūrinè urbanistinè vertè. Susiklostę miesto erdvių tipai Fig. 9. Master Plan of Druskininkai (executive:

S. Čereškevičius, architects: N. Dičiuvienè, J. Bučas,

L. Dringelis, A. Mačiulis, V. Stauskas, et al., 1997).

Urban-architectural value of the town's spatial structure and buildings. Existing types of urban spaces

grožį , konstatuojama architektūros savitumo stoka, siūloma statyti nedidelius pensionus ir pan. (Druskininkų miesto centrinès dalies ... 1987). Tais pačiais metais Statybos ir architektūros instituto mokslininkai parengè Druskininkų ir jų apylinkių kraštotvarkos schemą (darbo vadovas V. Stauskas, bendraautoriai G. Danulaitis, L. Dringelis, J. Bučas, dalyvavo R. Mickevičiui), kur pateikiamos naujos idejos plečiant kurorto funkcijas, išnaudojant apylinkių kraštovaizdžio ypatumus.

Atkūrus Lietuvos valstybingumą, keitèsi politinès, socialinès ir ekonominès sąlygos. Sovietmečiu kurorto plètra buvo orientuota daugiau gydymo tikslams, aptarnauti ligonius ir poilsiautojus iš Sovietų Sąjungos. Dabar, nors ir išlieka Druskininkų kurorto pagrindinė funkcija - gydomoji bei reabilitaciné, kartu kuriama nauja perspektyva - pramoginių paslaugų potencialas, vystant žirgų, vandens, teniso, golfo, orientacinị spor- 
tą, medžioklę, žvejybą ir pan. 1997 m. parengiamas naujas Druskininkų miesto bendrasis planas (darbo vadovas S. Čereškevičius, architektūrinès dalies vadovė N. Dičiuvienė, architektai J. Bučas, L. Dringelis, A. Mačiulis, V. Stauskas ir kt.), kuriame, panaudojant aplinkų gamtinị, etnokultūrinị bei istorinị potencialą, siūloma iš esmès nauja rekreacinio-pažintinio turizmo, kaip vienos iš prioritetinių kurorto veiklos sričių, programa. Šiame bendrajame plane siūloma koreguoti Druskininkų savivaldybès ribas, ịtraukiant teritorijas, turinčias palankias sąlygas etnoturizmui (Liškiava, Švendubrè, Latežeris ir kt.), unikalų kraštovaizdị kaimo turizmui (Mizarai, Kaziulai ir kt.), vandens sportui, pèsčiụjų, dviračių, slidžių turizmui, žirginiui turizmui (bazè Ricieliuose) plètoti, kempingams, golfo laukams ịrengti ir pan. Druskininkų miesto bendrajame plane išlieka išskaidytas planinès struktūros principas. Plane siūloma atsisakyti stambių ir didelio aukštingumo pastatų statybos, orientuotis i "statinius ne aukštesnius už medžius“ (Druskininkų miesto bendrasis planas ... 1997) (9 pav.). Stebina faktas, kad Druskininkų miesto savivaldybė, jos taryba delsè patvirtinti 1997 m. parengtą bendrąj t planą. Gal savivaldybès administracijai, miesto merui geriau „turèti laisvas rankas“, patiems savo nuožiūra spręsti miesto plètros klausimus? Ši ydinga praktika jau įsigali ir kituose Lietuvos miestuose. Šiuo metu rengiamas naujas Druskininkų miesto bendrasis planas.

\section{Išvados}

1. Druskininkuose susiformavo nevientisa, išskaidyta plano struktūra. Išskiriamos kelios miesto dalys: senamiestis, naujoji miesto dalis (vadinamoji Paganka), Kloniškès, Kalviškès, Ratnyčia ir Baltašiškè.

2. Druskininkų miesto erdves galima skirstyti $\mathfrak{i}$ keturis tipus: A - suformuotos, užbaigtos; B - nevisiškai suformuotos, jų architektūra dar gali tobulèti; C - indiferentiškos, „bejausmès“, kurias būtina tobulinti ir $\mathrm{D}$ - nesuformuotos, chaotiškos miesto erdvès, kurioms būtina architektūros raida.

3. Miesto siluetas formavosi palaipsniui. Iki sovietmečio miesto panoramoje vyravo žalieji masyvai. Po karo iki 1977 m. miesto siluetas ne daug kuo keitèsi. Vèliau kurorte statomi aukšti, stambūs sanatorijų kompleksai ir gyvenamieji namai, kurie, agresyviai iškilę žalioje miesto panoramoje, pažeidè gamtos ir architektūros darną.

4. Atkūrus Lietuvos valstybingumą, keitèsi kurorto pobūdis, nors ir išliko gydomoji bei reabilitacinè funkcija, kartu kuriama nauja perspektyva - plètojamos pramoginès paslaugos, rekreacinis pažintinis turizmas, naudojant apylinkių gamtinị, etnografinị bei istorinị potencialą.

\section{Literatūra}

Druskininkų miesto centrinès dalies suplanavimo projektas. 1970. Miestų statybos projektavimo institutas, Kauno filialas. Vadovas A. Steponavičius, autoriai V. Medelis ir kt. Kaunas.

Druskininku miesto generalinis planas. 1979. Miestų statybos projektavimo institutas, Kauno filialas. Vadovas P. Janulis, autoriai A. Pucas ir kt., dalyvavo V. Petkevičius. Kaunas.

Druskininku miesto centrinès dalies detalaus suplanavimo projektas. 1987. Miestų statybos projektavimo institutas, Kauno filialas. Autoriai: A. Pucas, J. Toliušienè ir kt., dalyvavo E. Pulavinskas. Kaunas.

Druskininku miesto bendrasis planas. 1997. Kurorto istorinè raida, kultūros vertybės ir paminklai. Susiklostę miesto erdvių tipai. Rekreacinė sistema apylinkėse. VGTU teritorijų planavimo mokslo institutas. Vadovas S. Čereškevičius, architektūrinès dalies vadovè N. Dičiuvienè, autoriai: J. Bučas, L. Dringelis, A. Mačiulis, V. Stauskas ir kt. Vilnius.

Jurkštas, V. 1994. Senamiesčių regeneracija. Architektūros harmonizavimo problema. Vilnius: Technika. 138 p.

Mačiulis, A. 2007. Druskininkų miesto architektūros apžvalga, Archiforma 37(1): 72-80.

Miškinis, A. 2002. Druskininkai, iš Rytų Lietuvos miestai ir miesteliai II, 1 knyga. Vilnius: Savastis, 301-323. ISBN 9986-420-45-8.

\section{PECULIARITIES OF SPATIAL AND PLANNED COMPOSITION OF DRUSKININKAI TOWN}

\section{A. Mačiulis}

Abstract. An unsustainable and resolved plan structure has been formed in Druskininkai. Completed urban spaces can be found only in the old town. The other parts of Druskininkai are dominated by chaotic, uncomplete spaces, which should be improved or formed again. New urban formations, especially high-rise buildings, which were built in the eighth and nineth decades, look aggressive and have changed the silhouette and panoramas of the town. When the Lithuanian independence was restored, Druskininkai, because of its beautiful surroundings, became not only a health resort but a recreational one as well.

Keywords: town plan structure, spatial composition, urban spaces, town silhouette, health and recreational resort.

\section{ALGIMANTAS MAČIULIS}

Doctor of the Humanities (architecture), Prof, Dept of Architecture, Vilnius Academy of Fine Arts, Maironio g. 6, LT-01124 Vilnius, Lithuania.

Teaching: architectural composition, the history of modern architecture, critical analysis of architecture. Membership: member of the LAS (Lithuanian Union of Architects). Publications: author of 90 scientific publications. Projects: author of 25 projects of architectural design. Research interests: modern processes in architecture, interaction between architecture and art. 